SJ Quinney College of Law, University of Utah

Utah Law Digital Commons

4-2021

Do You See What I See? The Science Behind Utah Rule of Evidence 617

Louisa Heiny

Follow this and additional works at: https://dc.law.utah.edu/scholarship

Part of the Criminal Procedure Commons, and the Evidence Commons 


\section{Do You See What I See? The Science Behind Utah Rule of Evidence $617^{1}$}

\section{Louisa M. A. Heiny ${ }^{2}$}

In late 1983, a ten-year-old boy named David was kidnapped and raped in Tucson, Arizona. Arizona v. Youngblood, 488 U.S. 51 (1988). At the hospital on the night of the assault he described his attacker as a black man with one bad eye. He worked with a police sketch artist and later identified his attacker on four different occasions. He identified the defendant twice in successive photo lineups, once in a courthouse hallway while waiting for a preliminary hearing, and twice in consecutive trials. The child's repeated and consistent identification of his attacker was - like most eyewitness identifications - incredibly persuasive to the jury. It was also - like some eyewitness identifications - absolutely wrong. Eighteen years after the attack, surviving DNA evidence showed that the perpetrator was not the man convicted of the crime but rather a serial rapist serving time in a Texas state prison. See Louisa M. A. Heiny \& Amos N. Guiora, Arizona v. Youngblood (Deep Dive SERIES) (forthcoming 2022).

Eyewitness identifications play a key role in many investigations and are often central to a prosecutor's case. As Justice Brennan recognized more than forty years ago, "[T]here is almost nothing more convincing than a live human being who takes the stand, points a finger at the defendant, and says 'That's the one!" Watkins

\footnotetext{
1 Thanks to Professor Teneille Brown at the University of Utah S.J. Quinney College of Law; the Honorable Richard McKelvie of the Third Judicial District for the State of Utah; and Mikayla Irvin and Darian Roberts, third year research assistants and J.D. candidates at the University of Utah S.J. Quinney College of Law for their help, research, and advice.

${ }^{2}$ Louisa M. A. Heiny is a Professor of Law at the University of Utah S.J. Quinney College of Law.
} 
v. Sowders, 449 U.S. 341, 352 (1981) (Brennan, J., dissenting) (quoting Elizabeth Loftus, Eyewitness Testimony 237-47 (1979)).

At the same time, eyewitness identifications can be tainted, accidentally or purposely, thus tainting the justice system as well. According to the Innocence Project, mistaken eyewitness identifications contributed to about sixty-nine percent of wrongful convictions in the United States overturned by exculpatory DNA evidence. Eyewitness Identification Reform, THE INNOCENCE PROJECT, https://www.innocenceproject.org/how-eyewitness-misidentification-can-sendinnocent-people-to-prison/ (last visited May 2, 2020).

There are myriad reasons for this phenomenon, but the primary responsibility lies not with the witness who, like David, is doing the best job possible after great trauma. Instead, the fault lies with a system that fails to recognize, and often amplifies, mistakes and assumptions in the identification process.

Prior to 2019, Utah courts used five "reliability" factors to determine the admissibility of eyewitness identifications. State v. Ramirez, 817 P.2d 774 (Utah 1991). ${ }^{3}$ In 2019, however, Utah became an early adopter of a new rule of evidence designed to increase the reliability of eyewitness identifications presented to juries. Utah Rule of Evidence 617 "ensures that when called upon, a trial court will perform a gatekeeping function and will exclude unreliable eyewitness

\footnotetext{
${ }^{3}$ State v. Ramirez, 817 P.2d 774 (Utah 1991). The five factors were: (1) the opportunity of the eyewitness to view the suspect; (2) the degree of attention paid to the suspect; (3) the witness's capacity to observe the even; (4) the degree of spontaneity and consistency thereafter of the eyewitness testimony; and (5) the nature of the event being observed.
} 
identification evidence in a criminal case." UTAH R. EvID. 617, Utah Supreme Court Advisory Committee on The Rules of Evidence general note [hereinafter "Committee Note"]. The starting point for determinations of eyewitness identification admissibility is now Rule 617. State v. Lujan, 20 UT 5, ๆ 4, 459 P.3d 992, 995.

Rule 617 serves a number of functions. First, it requires that the court exclude evidence if a factfinder "could not reasonably rely on the eyewitness identification." UTAн R. EvID. 617(b). Second, it places the burden on the party challenging the evidence to make the necessary showing of unreliability. Id. Third, it sets out factors that the court may use in determining reliability, including those that apply in all cases and those that apply specifically to lineups, photo arrays, and showups. UTAH R. EvID. 617(b)-(c). Fourth, it sets parameters for the admission of photographs. UTAH R. EVID. 617(d). Finally, it sets out the role of expert witnesses and jury instructions in helping the court and the jury assess the reliability of eyewitness identifications. UTAH R. EvID. 617(e)-(f). This article examines the factors courts may use in determining reliability, as well as the science underpinning the Rule. An upcoming article will discuss litigation at various trial stages under Rule 617.

\section{Eyewitness Identifications and Estimator Variables}

In all cases involving challenged eyewitness identifications, courts may consider nine estimator variables. Estimator variables are "factors connected to the event, witness, or perpetrator - items over which the justice system has no control," 
but which "may affect the reliability of an eyewitness account." Lujan, 20 UT 5, ๆ

37, 459 P.3d at 1001 (citations omitted).

They include (among others) the viewing conditions at the time of the event (distance, lighting, etc.), the amount of stress (or duress) the witness was under, whether there was a weapon that the witness focused on, witness characteristics (age, impairment, etc.), perpetrator characteristics (like age and race, given that witnesses are better at identifying persons of their own age and race), and factors affecting memory decay.

Id. (citation omitted). Thus, Rule 617 directs judges to consider:

(1) Whether the witness had an adequate opportunity to observe the suspect committing the crime;

(2) Whether the witness's level of attention to the suspect committing the crime was impaired because of a weapon or any other distraction;

(3) Whether the witness had the capacity to observe the suspect committing the crime, including the physical and mental acuity to make the observation;

(4) Whether the witness was aware a crime was taking place and whether that awareness affected the witness's ability to perceive, remember, and relate it correctly;

(5) Whether a difference in race or ethnicity between the witness and suspect affected the identification;

(6) The length of time that passed between the witness's original observation and the time the witness identified the suspect;

(7) Any instance in which the witness either identified or failed to identify the suspect and whether this remained consistent thereafter;

(8) Whether the witness was exposed to opinions, photographs, or any other information or influence that may have affected the independence of the witness in making the identification; and

(9) Whether any other aspect of the identification was shown to affect reliability.

UTAH R. EvID. 617(b)(1)-(9). 
Estimator variables have been extensively researched over the past fifty years by psychologists, law professors, and criminologists. The Utah Supreme Court Advisory Committee on the Rules of Evidence relied heavily on this research in drafting Rule 617 . The results of this research often run counter to the assumptions of fact-finders.

\section{Adequate Opportunity to Observe: Rule 617(b)(1)}

Whether a witness has "an adequate opportunity to observe the suspect committing the crime" may depend on fairly obvious factors such as the lighting conditions or length of observation. It may also depend on far more subtle factors such as the direction of the observer's gaze. Visual acuity is the highest at the observer's center of gaze. This center is the area that humans use for fine sensing, such as reading or scrutinizing faces in a social context. Acuity drops off markedly with angular distance from this center, as might be the case if a suspect were standing above or below the witness on a set of stairs, and "yields retinal distortions of facial features.” NATIONAL RESEARCH COUNCIL, IDENTIFYING THE CULPRIT: AssESSING EyeWITNESs IdENTIFICATION 56 (2014) [hereinafter Identifying the Culprit]. Even a ten-degree change from the center may make a difference. Identifying the Culprit at 51. Likewise, viewing conditions may also affect the perception of face, gender, and age. Investigators found that "faces that were physically identical were perceived as unambiguously male or female depending on where they appear in the observer's visual field." Identifying the Culprit at 56. 


\section{Weapon Focus and Other Distractions: Rule 617(b)(2)}

High and low levels of stress may harm performance in identifying suspects, while moderate levels may enhance memory performance. The presence of highlyemotional stimuli also has a counter-intuitive influence on a witness's identification. Many fact finders might assume that the presence of a weapon at the scene would improve the witness's recall. However, research suggests instead that a witness's attention in this scenario "is compellingly drawn to emotionally laden stimuli, such as a gun or a knife, at the expense of acquiring greater visual information about the face of the perpetrator." Identifying the Culprit at 55. The phenomenon of "weapon focus" means that the presence of a weapon at the scene of a crime captures the witness's visual attention and impedes the witness's ability to attend to other important features of the visual scene, such as the face of the perpetrator.

Further, humans are not hardwired to look at things that scare us, and thus a stressed victim may encode information differently. Zoom Interview with Dr. Gary L. Wells, Iowa State Univ. (July 21, 2020). Stress promotes enduring memory retention and a sense that the witness is "reliving" the event each time she repeats the story. These stories, because they are traumatic, are often retold. However, factors such as weapon-focus may make the memories inaccurate, and witnesses often fold information learned after the event into their memories. "With each implicit retrieval or explicit telling of a story," witnesses "may unconsciously smooth over inconsistencies or modify content based on our prior beliefs, the accounts of 
others, or through the lens of new information." Identifying the Culprit at 62

(citations omitted). During this process, a witness may also "add embellishments that reflect opinions, emotions, or prejudices rather than observed facts; or ... may simply omit disturbing content and pass over fine details." Identifying the Culprit at 62 (citations omitted). These vivid but increasingly inaccurate memories are often held with high confidence by the witness. "This breakdown of the relationship between accuracy and confidence can obviously undermine eyewitness accounts." Identifying the Culprit at 63-64.

Awareness That a Crime is Taking Place: Rule 617(b)(4)

Low levels of emotion attending any scene will also have an impact on the accuracy of an eyewitness account. Low levels of stress during the event may mean that details are ignored, as in the classic "Invisible Gorilla" psychology experiment in which viewers are asked to watch a video of a basketball game and count how many times the ball is passed. Fully $50 \%$ of viewers fail to notice that a man in a gorilla costume walks through the scene. See CHRISTOPHER CHABRIS \& DANIEL Simons, The INVISIBLE GoRILLA (2010). "In some cases, unattended content is effectively invisible: It does not reach awareness, it is not perceived, and it is not available ... for storage in memory." Identifying the Culprit at 53.

Own-Race Bias: Rule 617(b)(5)

The race of both the witness and the suspect plays a significant role in the accuracy of eyewitness identification. "[F]aces of people of races different from that of the eyewitness are harder to identify accurately than are faces of people of the 
same race as the eyewitness." Identifying the Culprit at 96 . This phenomenon, knowns as "own-race bias," does not reflect racial animus or bias. Instead it reflects, and is moderated by, the number of close relationships a witness has with people of a different race. It is not, however, moderated by the frequency of contact that a witness has with those of other races. A store clerk, for example, who has daily interaction with people of a variety of races but who has few or no friendships with those of different races may be subject to own-race bias. Interview with Dr. Gary L. Wells, Iowa State Univ. (July 21, 2020).

Repeat Identification and Exposure to Information: Rules 617(b)(7) and $617(b)(8)$

Rule 617 instructs judges to consider the frequency and consistency with which a witness identifies a suspect. UTAH R. EvID. 617(b)(7). While consistent identifications may indicate reliability, repeating an identification over time carries with it at least four dangers. First, it encodes the identified face, rather than the culprit's face, in the witness's memory. Interview with Dr. Elizabeth F. Loftus, Univ. of Wash. (June 24, 2020). Second, multiple procedures can create a commitment effect in which the witness recognizes a lineup participant or suspect photo from a previous procedure rather than from the crime scene. Over time witnesses, who often don't want to disappoint police or prosecutors, may become concerned about picking the same person at each opportunity rather than picking the right person at each opportunity. Interview with Dr. Gary L. Wells, Iowa State 
Univ. (July 21, 2020). Third, repeat exposure to a suspect may cause a witness to become more confident in her identifications, regardless of their accuracy.

Finally, repeat identification procedures also increase the likelihood that the witness will be "exposed to opinions, photographs, or any other information or influence that may have affected the independence of the witness in making the identification," UTAH R. EvID. 617(b)(8), such as accidental or overt confirmation that the witness has made the "correct" choice or exposure to other witnesses and their identifications. "A witness' inevitable interactions with law enforcement and legal counsel, not to mention communications from journalists, family, and friends, have the potential to significantly modify the witness' memory of faces encountered and of other event details at the scene of the crime." Identifying the Culprit at 65.

\section{Lineups, Showups, and System Variables}

In addition to estimator variables, judges must also grapple with system variables. "System variables consist of factors controlled by the court or law enforcement.” See Lujan, 20 UT 5, ๆ 38 (2020). These include the procedures used during the identification process; the quality of pre-identification instructions; and proper photo array, lineup, or showup construction. Id. Rule 617 directs judges to consider a variety of system variables and requires the court to "determine whether the identification procedure was unnecessarily suggestive or conducive to mistaken identification. If so, the eyewitness identification must be excluded unless the 
court," considering the best practices for controlling system variables, "finds that there is not a substantial likelihood of misidentification.” UTAH R. EVID. 617(c).

\section{Use of Composite Sketches}

In some jurisdictions, the first step in the identification procedure is to ask the witness to work with a police sketch artist to create a composite drawing. However, current research has identified three problems with these sketches. First, controlled studies have shown that the actual face of a perpetrator is generally much different than the composite that was drawn. Interview with Dr. Gary L. Wells, Iowa State Univ. (July 21, 2020). This may be because witnesses have difficulty accurately describing specific features of a face. Id. Instead, distinguishing features will stand out and possibly distract from other features. To illustrate this point, think of a person you know well, such as a parent or child, and attempt to describe the shape of that person's nose. Consider the difficulty of repeating that experiment with a person you have seen only briefly and perhaps under less-thanideal circumstances such as low lighting. Second, specific questions such as "tell me what you remember about the robber's nose?" may lead the witness to try and remember something that she doesn't know. Id. Allowing a witness to generally tell an investigator what she remembers will lead to more accurate information. Id. Third, completing a composite tends to lock the drawing into the creator's memory, which can encode a new face in their memory that is different from the actual face. Because this further erodes the reliability of later identifications, such as those that 
might occur at a pretrial hearing or trial, experts no longer recommend that witnesses create a composite sketch. $I d$.

Best Practices in Photo Arrays and Lineup Procedures: Rule 617(c)(1)-(2)

Photo arrays and lineups provide the government with the ability to control the identification environment. Best practices, designed to generate the most reliable identification, require care in the choice of photographs or participants in the lineup, the manner of presentation, the instructions to witnesses, and the documentation of the witness's response.

Police must, of course, use lineup participants or photos of those "who match the witness's description of the perpetrator and who possess features and characteristics that are reasonably similar to each other, such as gender, race, skin color, facial hair, age, and distinctive physical features.” UTAH R. EvID. 617(c)(1)(C)(i). The process of creating a photo array should be automated, "using the same or sufficiently similar process or formatting," be computer-generated where possible, and contain no writing. UTAH R. EvID. 617(c)(1)(iii)-(iv); UTAH R. EvID. 617 Committee Note $\S(c)(1)$. One way to test the array for fairness is to ask a random sample of non-witnesses who they believe to be the suspect in the array. If the non-witnesses in the experiment consistently pick the real suspect, or if the choices are not distributed evenly, the array is problematic and should be reconstituted. Interview with Dr. Gary L. Wells, Iowa State Univ. (July 21, 2020).

Police must also ensure that each photo array or lineup contains only one suspect and five “fillers." U.S. DEPT. OF JUSTICE, EyeWitness IDENTIFICATION: 
Procedures for Conducting Photo ARrays (2017) at 3.1 [hereinafter D.O.J.

PROCEDURES]. A filler is a non-suspect such as a police officer or currently incarcerated inmate who could not have committed the crime. If a lineup is entirely composed of suspects an eyewitness cannot fail in his or her choice - even if that choice is a random one. The inclusion of fillers makes it more likely that a random choice will be a wrong one and thus helps to prevent mistaken identifications.

Similarly, the photo array or lineup must contain at least one suspect. Most witnesses will choose someone during the identification procedure, even if the real perpetrator is not present. In cases of multiple suspects, the witness should be asked to view multiple arrays or lineups and should be told in advance that she will be asked to view more than one array. Each array should again contain only one of the possible suspects and five new filler subjects. D.O.J. PROCEDURES at 3.6. If the suspect has a remarkable feature, such as a facial scar, the fillers should match the suspect's feature or photos should be doctored to appear as if they do. D.O.J. PROCEDURES at 3.3. In the case of multiple witnesses, each should be shown the photo array or lineup in separate procedures, and the suspect should be placed in different positions each time. UTAH R. EVID. 617(c)(1)(E)(i)-(ii).

Because witnesses tend to pick someone during an identification procedure regardless of whether the actual perpetrator is present, law enforcement should not tell the witness that a suspect is in custody. Instead, law enforcement should always instruct the witness in a "neutral and detached way," UTAH R. EVID. 617 Committee Note $\S(c)(1)$, that the person "who committed the crime may or may 
not be depicted in ... the photos," that "it is as important to clear a person from suspicion as to identify a wrongdoer," the person in the photo "may not appear exactly as he or she did on the date of the incident because features such as weight and head and facial hair may change," and perhaps most importantly, that "the investigation will continue regardless of whether an identification is made." UTAH R. EvID. 617(c)(1)(B)(i)-(iv). Those instructions should be signed and dated by the witness. The witness should also be given an opportunity to "ask questions about the instructions before the process begins." UTAH R. EvID. 617 Committee Note. Once the witness begins the viewing process, "the person conducting the procedure should not interrupt the witness or interject." Utah R. Evid. 617 Committee Note $\S$ (c)(1); D.O.J. PROCEDURES at 6.2.

The identification procedures should be recorded, and the witness's response should be documented. The response should include a "confidence statement" in which "law enforcement timely asked the witness how certain he or she was of any identification." Utah R. Evid. 617(c)(1)(D). The question generating the confidence statement can be as simple as asking the witness, "how sure are you?" A witness doesn't need to quantify the answer, but the administrator may ask follow-up questions. For example, if the witness is vague in his or her answer, such as, "I think it's number 4," the administrator should say, "you said, 'I think it's \#4.' What do you mean by that?" D.O.J. PROCEDURES at 8.3. The responses, including verbal responses, gestures, and reactions, should be documented verbatim at the time that the statement is given. 
A confidence statement is an integral part of the identification because an initial confidence statement is often a more reliable predictor of eyewitness accuracy than is a witness's confidence at the time of trial. However, the confidence statement must be taken at the time of the procedure. Waiting to ask for a confidence statement will often create hindsight bias and cause the witness to believe that she was sure in her identification all along-even if she was not. Interview with Dr. Gary L. Wells, Iowa State Univ. (July 21, 2020).

Finally, and perhaps most importantly, law enforcement should use double blind procedures through the identification process. In a double blind identification procedure the person who conducts a lineup or organizes a photo array and all those present in the room during the procedure (except defense counsel) should be unaware of which person is the suspect. UTAH R. EvID. 617 Committee Note $\S(c)(1)$.

A double blind procedure assures that the procedure is conducted by an administrator who is not involved in the investigation and has no information about the suspect. This type of neutral administrator is less likely to signal the identity of the suspect or even signal that the perpetrator is in the lineup or the photo array. Signals from a procedure administrator may be intentional or inadvertent and may be verbal or non-verbal. Verbal cues sometimes occur prior to the identification, for example, when an officer tells a witness, "we found the guy with your credit cards and just need you to ID him" or "we arrested someone we want you to identify." Verbal cues also occur during or after the identification, for example, if an officer says, "good job," or "you picked the right guy." Post-identification feedback 
artificially boosts the confidence of a witness and ultimately contaminates any trial identification. Interview with Dr. Elizabeth F. Loftus, Univ. of Wash. (June 24, 2020). Non-verbal cues may be subtle but impactful, for example, holding a photo array with a finger pointed at the suspect, nodding after an identification, or even making eye contact with another officer in the room.

In some circumstances a double blind procedure will prove impossible. This could occur, for example, in some smaller jurisdictions, circumstances where the witness will only participate in a procedure conducted by the investigating officer, or in high-profile investigations where all members of a law enforcement officials are aware of the identity of a suspect. In these situations the agency may need to use "blinded" identification procedures. D.O.J. PROCEDURES at 5.2.

In a blinded procedure the administrator is aware of the identity of the suspect but is unaware of which photo a witness is viewing at a particular time. For example, the administrator could place photos for the photo array in separate folders, shuffle the folders so she can't see the order or arrangement of the photographs, and then sit in a place where she can't see which photo the witness is viewing at any time. D.O.J. PROCEDURES at 5.3. These blinded procedures are only possible for photo arrays. Lineups must be conducted using double blind procedures. UTAH R. EvID. 617 Committee Note § (c)(1).

Regardless of whether the administration is double blind, blinded, or neither, the procedure should be audio or video recorded. Witness statements, gestures, and non-verbal reactions should be written down and confirmed by the witness, and law 
enforcement should "refrain $]$ from giving any feedback regarding the identification.” UTAH R. EvID. 617(C)(1)(D)(ii); D.O.J. ProcedURES at 9.1.

\section{Special Considerations for Showup Procedures}

Showups often occur soon after the reported crime, which may increase the reliability of the identification. They also permit the quick release of suspects early in the investigation and may be necessary for the development of probable cause. American Bar Association, American Bar Association Statement of Best Practices For Promoting the AcCURACy of Eyewitness Identification PROCEDURes (2004), https://www.nacdl.org/Document/American-Bar-AssociationStatement-of-Best-Practic (last visited Jan. 9, 2021).

However, showups carry an additional risk of eyewitness misidentification. Identifications during showups are less reliable than those generated by properlyconstructed lineups. $I d$. The witness is usually shown a single person who matches the witness's original description of the perpetrator. The suspect may be wearing clothing or have other distinguishing features that match the witness's original description. The suspect may be located close to the crime scene and may be clearly in police custody at the time of the identification. All of these factors overtly or subtly influence the identification process.

To determine whether a showup was "unnecessarily suggestive or conducive to mistaken identification," judges should consider many of the same factors they consider in evaluating other identification procedures. UTAH R. EvID. 617(c)(2). As with lineups and photo arrays, law enforcement should instruct the witness that the 
person she is viewing may or may not be the suspect. UTAH R. EvID. 617(c)(2)(C) and should record a witness confidence statement immediately following the procedure. Because it is impossible to conduct a double blind or blinded showup, law enforcement must take care not to "suggest[], by any words or actions, that the suspect is the perpetrator." UTAH R. EvID.. 617 (c)(2)(C)(I).

Judges should additionally consider a variety of factors that can independently taint an identification made during a showup. Judges should consider the location of the showup and question whether the showup was conducted "at a neutral location as opposed to law enforcement headquarters or any other public safety building," and whether "the suspect was in a patrol car, handcuffed, or physically restrained by police officers." Equally important is whether "law enforcement documented the witness's description prior to the showup," and whether the same suspect was presented "to the witness more than once." Judges should also consider superficial ways that the suspect might match the description of the perpetrator, such as whether the suspect was required to "wear clothing worn by the perpetrator," "confirm his or her appearance in any way to the perpetrator," "speak any words uttered by the perpetrator," or "perform any actions done by the perpetrator." In the case of multiple witnesses, law enforcement should take "steps to ensure that" multiple witnesses "were not permitted to communicate with each other regarding the identification of the suspect." UTAH R. EvID. 617(c)(2)(2). 
Additionally, the court may consider whether the showup was "reasonably necessary to establish probable cause." Because showups carry an inherent risk of unreliability, it is foolhardy to taint an identification procedure if it is not strictly necessary. "Once law enforcement has probable cause to arrest a suspect ... a witness should not be allowed to participate in showup proceedings but should participate only in lineup or photo array procedures." UTAH R. EVID. 617 Committee Note $\S(c)(1)$.

\section{Other Relevant Circumstances}

In addition to identification procedures, a "court may evaluate an identification procedure using any other circumstance that the court determines is relevant." UTAH R. EvID. 617(c)(3). One particularly relevant additional circumstance is the amount of time it took the witness to make an identification. Identification accuracy is largely diminished after thirty seconds of consideration. If the real perpetrator is included in the photo array, lineup, or showup, the witness will usually make an identification within a few seconds. Interview with Dr. Gary L. Wells, Iowa State Univ. (July 21, 2020).

\section{Part II Coming Attractions}

In Part II of this series we will examine how and when to litigate issues surrounding eyewitness identification, when and how to include expert opinions and testimony, effective cross-examination of eyewitness testimony, and the role of jury 
instructions to help jurors understand factors that influence witness perception and memory and judge the reliability of eyewitness identification. 